\title{
Comparison and performance of two cosmogenic nuclide sample preparation procedures of in situ produced ${ }^{10} \mathrm{Be}$ and ${ }^{26} \mathrm{Al}$
}

\author{
Zsófia Ruszkiczay-Rüdiger ${ }^{1}$ (D) - Stephanie Neuhuber ${ }^{2} \cdot$ Régis Braucher $^{3} \cdot$ Johannes Lachner $^{4,6} \cdot$ Peter Steier $^{4}$. \\ Alexander Wieser ${ }^{4}$. Mihály Braun ${ }^{5}$. ASTER Team ${ }^{3}$
}

Received: 3 June 2021 / Accepted: 21 July 2021 / Published online: 18 August 2021

(c) The Author(s) 2021

\begin{abstract}
Cosmogenic radionuclide ${ }^{10} \mathrm{Be}$ and ${ }^{26} \mathrm{Al}$ targets $\left(\mathrm{BeO}\right.$ and $\left.\mathrm{Al}_{2} \mathrm{O}_{3}\right)$ for $\mathrm{AMS}$ analysis are produced by a growing number of geochemical laboratories, employing different sample processing methods for the extraction of $\mathrm{Be}$ and $\mathrm{Al}$ from environmental materials. The reliability of this geochronological tool depends on data reproducibility independent from the preparation steps and the AMS measurements. Our results demonstrate that ${ }^{10} \mathrm{Be}$ and ${ }^{26} \mathrm{Al}$ concentrations of targets processed following different, commonly used protocols and measured at two AMS facilities lead to consistent results. However, insoluble fluoride precipitates, if formed during processing, can cause decreased ${ }^{26} \mathrm{Al}$ results, while ${ }^{10} \mathrm{Be}$ concentrations are unaffected.
\end{abstract}

Keywords Cosmogenic radionuclides $\cdot \mathrm{Al} \cdot \mathrm{Be} \cdot$ Comparison of laboratory protocols $\cdot$ Fluoride precipitates

\section{Introduction}

Cosmogenic in situ produced radionuclides (CRN) are widely used in geomorphology and Quaternary geology by allowing direct age determination of landforms and measurement of denudation rates over $10^{2}$ to $10^{6}$ timescales [1-3]. However, the power of this geochronological tool strongly depends on the accuracy, precision and reproducibility and thus comparability of data provided by different laboratories, both for sample preparation and for Accelerator Mass

Zsófia Ruszkiczay-Rüdiger

rrzsofi@geochem.hu

Stephanie Neuhuber

stephanie.neuhuber@boku.ac.at

Régis Braucher

braucher@cerege.fr

Johannes Lachner

johannes.lachner@univie.ac.at

Peter Steier

peter.steier@univie.ac.at

Alexander Wieser

alexander.wieser@univie.ac.at

Mihály Braun

mbraun@atomki.mta.hu
Spectrometry (AMS) measurements. It is critical for the reliability of the results to obtain the same nuclide concentrations within uncertainties for a sample, regardless of the methodology followed during sample processing and AMS measurement.

In this study, an inter-laboratory comparison of two different sample processing methodologies carried out at two cosmogenic nuclide sample preparation laboratories (Cosmo-lab) is presented. The main objective of the comparison was to verify if CRN results are independent of the

Institute for Geological and Geochemical Research, Research Centre for Astronomy and Earth Sciences, Eötvös Loránd Research Network, Budaörsi út 45, Budapest 1112, Hungary

2 Institute of Applied Geology, University of Natural Resources and Life Sciences, Peter Jordan Strasse 82, 1190 Vienna, Austria

3 Aix-Marseille University, CEREGE, CNRS-IRD, INRAE, Collége de France - INRAE UM34, Aix-en-Provence, France

4 Faculty of Physics, University of Vienna, Währinger Strasse 17, 1090 Vienna, Austria

5 Hertelendi Laboratory of Environmental Studies, Institute of Nuclear Research, Bem tér 18/c, Debrecen 4001, Hungary

6 Present Address: Accelerator Mass Spectrometry and Isotope Research, Helmholtz-Zentrum Dresden-Rossendorf, Bautzner Landstraße 400, 01328 Dresden, Germany 
sample processing method and of the involved laboratory facility. At Budapest ${ }^{1}$ chemical sample processing followed the procedures used at LN2C (CEREGE, Aix en Provence) adapted from Brown et al. [4], Merchel and Herpers [5] and also described by Merchel et al. [6] (MH). At Vienna, ${ }^{2}$ procedures adapted from Kohl and Nishiizumi [7] and Granger et al. [8] were followed (KNG).

Although the quartz purification and geochemical procedures for rock digestion and ion separation are welldescribed for both protocols, several potential complications exist. In particular, insoluble metal-fluoride precipitation during sample dissolution and evaporation and its effect on trapping ${ }^{10} \mathrm{Be}$ and ${ }^{26} \mathrm{Al}$ was monitored. For this purpose, the full $\mathrm{MH}$ nuclide extraction protocol was compared to a simplified and faster version of the same protocol to test if results are robust using the fast track. Also, the suitability of the Microwave Plasma - Atom Emission Spectrometry (MPAES) method for the determination of the total $\mathrm{Al}$ content of the samples was tested. One further goal was to monitor the background in the Cosmo-labs of Budapest and Vienna to see if it was low enough for reliable and repeatable cosmogenic nuclide data production.

These objectives are achieved by the comparison of the ${ }^{10} \mathrm{Be}$ and ${ }^{26} \mathrm{Al}$ concentrations in quartz in aliquots of a natural sample set of 12 samples from a fluvial terrace of the Danube River and in six aliquots of the CoQtz-N reference quartz material [9] processed using both $\mathrm{MH}$ and KNG extraction schemes. From the CoQtz-N two additional aliquots were processed by the KNG scheme only for ${ }^{10} \mathrm{Be}$ determination.

For two samples (Dan14-14 and -25) no comparison is possible because only a single assay was processed. Their ${ }^{10} \mathrm{Be}$ and ${ }^{26} \mathrm{Al}$ concentrations are included in this study in order to provide the complete dataset for further use.

\section{Theory}

Cosmogenic in situ produced ${ }^{10} \mathrm{Be}$ and ${ }^{26} \mathrm{Al}$ are formed by the interaction of secondary cosmic rays with $\mathrm{Si}$ and $\mathrm{O}$ in quartz and are retained in the mineral lattice [10]. They are radioactive with half-lives of $1.387 \pm 0.012 \mathrm{Ma}$ for ${ }^{10} \mathrm{Be}[11$, 12] and $0.705 \pm 0.017 \mathrm{Ma}$ for ${ }^{26} \mathrm{Al}$ [13]. Their concentration in quartz at the time of sampling depends on their production by cosmic rays and loss by radioactive decay and denudation. Pure quartz mineral separates are required for extraction of cosmogenic ${ }^{10} \mathrm{Be}$ and ${ }^{26} \mathrm{Al}$ to resolve geological and geomorphological issues as their productions have been

\footnotetext{
${ }_{1}^{1}$ http://www.geochem.hu/kozmogen/Lab_en.html

${ }^{2}$ https://boku.ac.at/baunat/iag/arbeitsgruppen-forschungsschwerpunk te/quartaerforschung/labor-fuer-kosmogene-nuklide.
}

calibrated within this mineral [1-3]. However, the direct comparison and joint analysis of the published results relies on the hypothesis that the reported cosmogenic ${ }^{10} \mathrm{Be}$ and ${ }^{26} \mathrm{Al}$ concentrations are similar within uncertainties, regardless of the facility and protocol of sample preparation and AMS device involved in the data acquisition. The present study aims at testing this hypothesis.

\section{Experimental}

\section{Sample collection}

The Vienna Basin is located between the Eastern Alps and the Western Carpathians and developed during the Miocene [14]. Fluvial terraces located on intra-basinal hills $[15,16]$ within the extensional structure of the Vienna Basin have been dissected by faults related to the Vienna Basin Transform Fault.

The sample set was taken from a $12 \mathrm{~m}$ thick fluvial sandygravel succession of a terrace on the intra-basinal hills south of the Danube east of the village of Haslau an der Donau (48.1141 N, 16.74342E, $189 \mathrm{~m}$ asl.; $40 \mathrm{~m}$ relative height Figs. 1, 2). Based on geomorphological mapping, its age is Middle Pleistocene [17], and thus within the range of burial age determination using the cosmogenic nuclide pair of ${ }^{10} \mathrm{Be}$ and ${ }^{26} \mathrm{Al}$. The samples were taken from the undisturbed terrace material exposed in an active gravel pit (Figs. 1, 2).

Samples for CRN analysis were collected from $5.5 \mathrm{~m}$ and $11.5 \mathrm{~m}$ subsurface depths. At each level six quartz cobbles were taken from the cobble-rich sandy gravel (Fig. 2). The cobbles were either quartzite or hydrothermal bluish (vein) quartz. At the base of the quarry, muscovite-rich upper Miocene (Pannonian) sand was exposed.

\section{Physical sample processing}

The goal of physical sample processing is to remove accessory minerals and thus to obtain a quartz-enriched sample aliquot. The cobbles were washed to remove attached grains, crushed and sieved and the $250-1000 \mu \mathrm{m}$ grain size fraction of each sample was split into two sub-samples that were processed at the two laboratories. The crushed cobbles were magnetically separated in Vienna. In Budapest density separation using LST fastfloat was applied to remove heavy minerals and feldspars, if necessary.

\section{Chemical sample processing}

The first phase of chemical sample processing is chemical etching of the samples. The objective in this phase is to dispose of minerals that are not completely removed by physical treatment. For instance, intergrown minerals of 


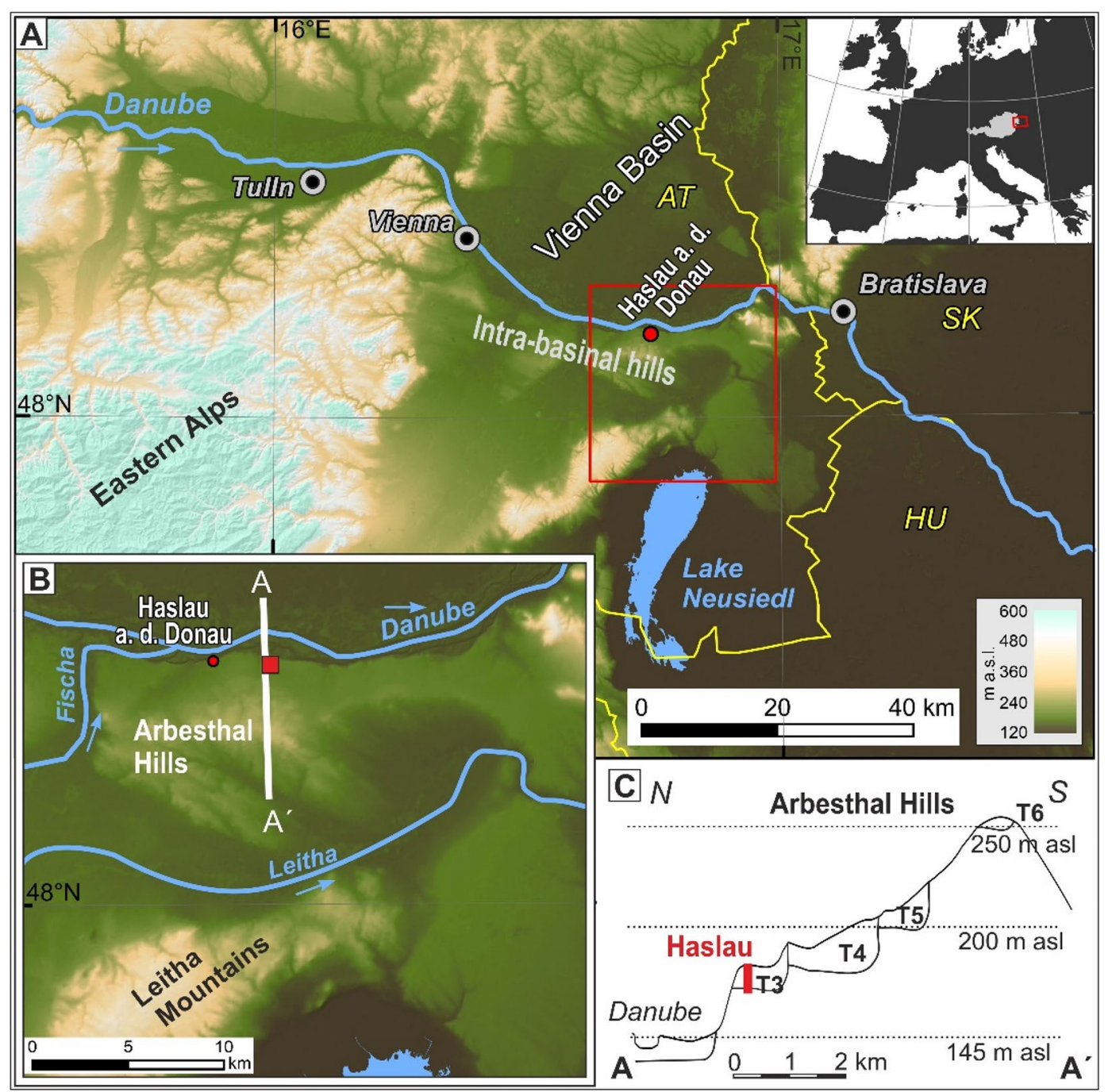

Fig. 1 A Overview of the Vienna Basin. Red rectangle shows the location of inset B. B Close-up of the intra-basinal hills with the location of the cross-section of inset $\mathbf{C}$ (A-A' section). C Cross-section through the Arbesthal Hills with the terrace levels indicated (T3-T6). Red rectangles on instets $\mathrm{B}$ and $\mathrm{C}$ show the location of the studied profile. (Color figure online) the feldspar group are often still present in the physically cleaned quartz. A second objective of the chemical etching of the quartz is to remove atmospheric ${ }^{10} \mathrm{Be}$ that may be adsorbed to the surface of quartz grains or in fissures within the mineral. Tables 1 and 2 present the successive steps applied at each lab needed to reach pure mineral separate.

The purity of the sample can be tested by different methods. For instance, microscopy [6] in combination with XRD to determine its mineralogy or by digesting a small aliquot to determine its $\mathrm{Al}$ content using ICP. If the quartz is successfully purified and is low in Al, it can pass to the next sample preparation phase, when cosmogenic ${ }^{10} \mathrm{Be}$ and ${ }^{26} \mathrm{Al}$ are released from the quartz lattice by total dissolution of the sample.
Once pure quartz is obtained and carefully weighted, ${ }^{9} \mathrm{Be}$ carrier is added before its total dissolution. ${ }^{9} \mathrm{Be}$ is always added because the natural ${ }^{9} \mathrm{Be}$ is too low to ensure an accurate determination of the ${ }^{10} \mathrm{Be} /{ }^{9} \mathrm{Be}$ ratio. The amount of ${ }^{9} \mathrm{Be}$ in the sample is calculated from the carrier weight, no additional measurement is involved. ${ }^{27} \mathrm{Al}$ carrier may be added together with the ${ }^{9} \mathrm{Be}$ or just before ion chromatography, depending on the timing of the determination of the natural $\mathrm{Al}$ content of the samples. ${ }^{27} \mathrm{Al}$ carrier is added only if the natural $\mathrm{Al}$ content is too low; however, in most cases its addition is not required.

The purified quartz is dissolved in HF by the formation of $\mathrm{SiF}_{4}$. As HF solution is not easy to handle, it is evaporated leaving behind elements from within the quartz lattice in a precipitate ("cake"). This precipitate can vary considerably 


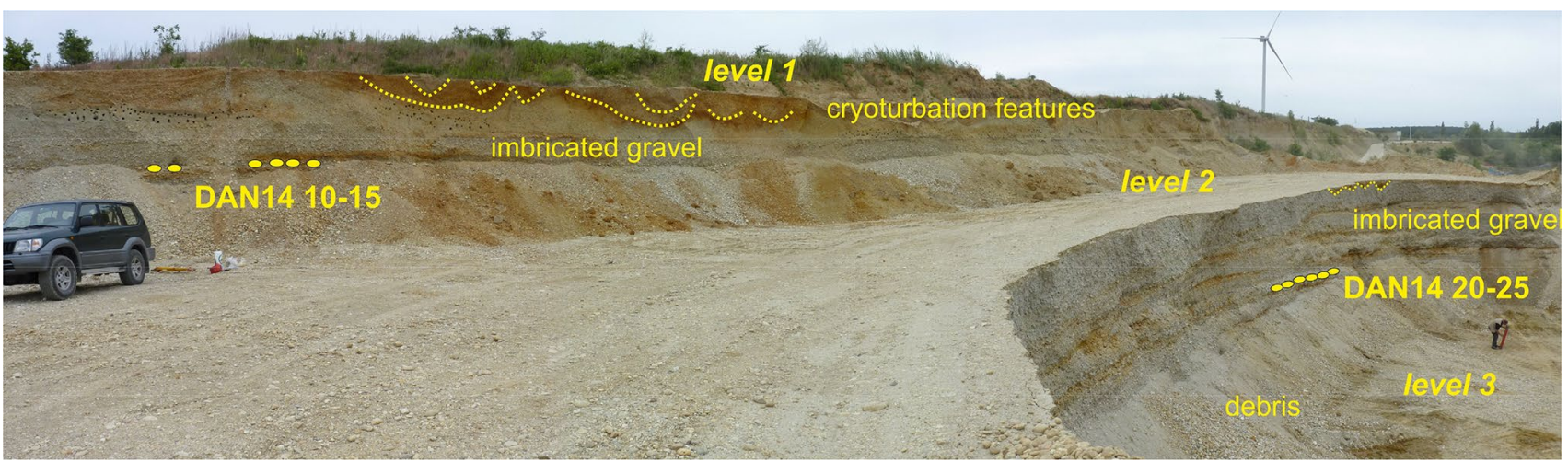

Fig. 2 Photo of the quarry of the sampled terrace at Haslau an der Donau

Table 1 Chemical sample processing steps of the MH protocol [4-6] applied in the Cosmo-lab of Budapest

\begin{tabular}{|c|c|c|}
\hline & Step & Description \\
\hline 1.1 & Quartz cleaning & $\begin{array}{l}\mathrm{HCl}(37 \%) / \mathrm{H}_{2} \mathrm{SiF}_{6}(31 \%)(1: 1) \text { leaching at room temperature on shaker table, repeated 3-6 times (or } \\
\text { more if necessary), at least } 24 \mathrm{~h} / \text { repetition, (preferentially } 48 \mathrm{~h} \text { ) }\end{array}$ \\
\hline 1.2 & Quality control & $\begin{array}{l}\text { Optical microscope, XRD (if at least } 98 \% \text { quartz, ready for digestion, if less, back to leaching) } \\
\text { if passed: proceed to next step; if failed: back to } 1.1\end{array}$ \\
\hline 1.3 & Removal of meteoric $\mathrm{Be}$ & $\begin{array}{l}\text { Removal of outer parts of the grains: about } 30 \% \text {, i.e. } 3 \text {-times } 10 \% \text {, of purified quartz by stoichiomet- } \\
\text { ric dissolution in HF ( } 48 \%) \text { at room temperature on a shaker table }\end{array}$ \\
\hline & Weighing & Weighing of pure quartz (readability: $0.01 \mathrm{mg}$ ) \\
\hline 2.1 & Addition of ${ }^{9} \mathrm{Be}$ carrier & $\begin{array}{l}\text { Addition of }{ }^{9} \mathrm{Be} \text { carrier: } 300 \mu \mathrm{l} \text {; note exact weight } \\
\text { Carrier type: Scharlab, BE0350100 (1000 mg/l, } 980.39 \mathrm{ppm}) \text {, }\end{array}$ \\
\hline 2.2 & Quartz dissolution & $\begin{array}{l}\text { Quartz dissolution in } \mathrm{HF}(48 \%)(3.6 \times \text { sample weight }+30 \mathrm{ml}) \text { at room temperature on a shaker table } \\
\text { in the presence of Be carrier }\end{array}$ \\
\hline 2.3 & Evaporation of $\mathrm{HF}-\mathrm{HNO}_{3}$ & $\begin{array}{l}\text { (1) After adding } \sim 30 \mathrm{ml} \mathrm{HNO}_{3}(65 \%) \text { the sample-HF solution is evaporated to dryness on hot plate } \\
\text { (2) } 2 \times 5 \mathrm{ml} \mathrm{HF} \text { is added and evaporated to dryness and } 1 \times 5 \mathrm{ml} \mathrm{HClO}_{4}(70 \%) \text {, is added and evapo- } \\
\text { rated to dryness. This step was omitted when the simplified protocol was tested } \\
\text { (3) The samples are re-dissolved in } 2 \mathrm{ml} \mathrm{HCl}(31 \%) \text {, then diluted to } 10 \mathrm{ml} \text { with } \mathrm{H}_{2} \mathrm{O} \text { and homog- } \\
\text { enised (note exact weight) } \\
\text { (4) } 500 \mu \mathrm{l} \text { aliquot is taken for the determination of native } \mathrm{Al} \text { content (note exact weight) }\end{array}$ \\
\hline 2.4 & Addition of ${ }^{27} \mathrm{Al}$ carrier & $\begin{array}{l}\text { Al carrier is added if the natural } \mathrm{Al} \text { content of the sample does not reach } 2 \mathrm{mg} \text { (Merck, 119,770, } \\
1000 \mathrm{mg} / \mathrm{l} ; 983.28 \mathrm{ppm})\end{array}$ \\
\hline 3.1 & Ion exchange and sample purification & $\begin{array}{l}\text { Ion exchange chromatography } \\
\text { (1) } \mathrm{pH} \text { selective hydroxide precipitation in } \mathrm{NH}_{3 \mathrm{aq}}(\mathrm{pH} 8-9) \\
\text { (2) anion exchange (Dowex } 1 \mathrm{X8} 8,100-200 \mathrm{mesh}) \\
\text { (3) volume reduction by evaporation and } \mathrm{pH} \text { selective hydroxide precipitation in } \mathrm{NH}_{3 \mathrm{aq}}(\mathrm{pH} 8-9) \\
\text { (4) cation exchange (Dowex } 50 \mathrm{WX} 8,100-200 \text { mesh), separation of } \mathrm{Be} \text { and } \mathrm{Al} \\
\text { (5) volume reduction by evaporation and } \mathrm{pH} \text { selective hydroxide precipitation }(\mathrm{pH} 8-9) \\
\text { (6) cleaning of the hydroxides by } 2 \times \text { rinsing with } \mathrm{H}_{2} \mathrm{O} \mathrm{pH} 8-9\end{array}$ \\
\hline 3.2 & Ignition & Ignition of the hydroxides at $900^{\circ} \mathrm{C}$ in muffle furnace \\
\hline 4 & Preparation of AMS measurement & $\begin{array}{l}\text { Mixing with } \mathrm{Nb} \text { and } \mathrm{Ag} \text { powder }\left(\mathrm{BeO} \text { and } \mathrm{Al}_{2} \mathrm{O}_{3} \text {, respectively), and loading into } \mathrm{Cu} \text { cathodes. This }\right. \\
\text { step occurred at ASTER AMS facility }\end{array}$ \\
\hline
\end{tabular}

in size depending on the purity of the quartz (i.e. the mass of elements trapped in the lattice, and also on the success of quartz purification during the previous sample preparation steps) and may contain metal-fluorides. To break-up these insoluble metal-fluorides they are converted into soluble chlorides by $\mathrm{HClO}_{4}\left(\mathrm{MH}\right.$ scheme) or sulfates by $\mathrm{H}_{2} \mathrm{SO}_{4}$ (KNG scheme).

In the next phase all interstitial ions that were trapped in the quartz crystal itself are removed and $\mathrm{Be}$ and $\mathrm{Al}$ 
Table 2 Chemical sample processing steps of the KNG protocol [7, 8] applied in the Cosmo-lab of Vienna

\begin{tabular}{|c|c|c|}
\hline & Step & Description \\
\hline 1.1 & $\begin{array}{l}\text { Removal of meteoric Be and Feld- } \\
\text { spars }\end{array}$ & HF- $\mathrm{HNO}_{3}(5 \mathrm{vol} \%)$ leaching overnight on heated "hot dog roller" \\
\hline 1.2 & Quartz separation & Density separation using LST fastfloat to remove heavy minerals and feldspars \\
\hline 1.3 & Removal of meteoric Be & $\mathrm{HF}-\mathrm{HNO}_{3}(5 \mathrm{vol} \%)$ leaching over night on heated "hot dog roller" \\
\hline 1.4 & Quality control Al content & $\begin{array}{l}\text { Dissolution of } 250 \mathrm{mg} \text { sample aliquot for } \mathrm{Al} \text { determination, if below } 200 \mathrm{ppm} \text { ready for digestion, if } \\
\text { above back to leaching }\end{array}$ \\
\hline 2.1 & Carrier addition & $\begin{array}{l}\text { Carrier addition (home-made Be carrier: concentration } 6445 \mathrm{ppm} 2 \% \text { err) in } 2 \% \mathrm{HNO}_{3} \\
\text { If required (Al below } 2 \mathrm{mg} \text { total mass) addition of a } 1000 \mathrm{mg} / \mathrm{Al} \text { carrier (Merck Certipur ICP } \\
\text { standard traceable to SRM from NIST) }\end{array}$ \\
\hline 2.2 & Quartz dissolution & Quartz dissolution in $\mathrm{HF}(48 \%)(5 \times$ sample weight $)$ and $\mathrm{HNO}_{3}(68 \%)(1 \times$ sample weight $)$ at $150{ }^{\circ} \mathrm{C}$ \\
\hline 2.3 & Evaporation of $\mathrm{HF}-\mathrm{HNO}_{3}$ & $\begin{array}{l}\text { After total dissolution of quartz: } \\
\text { (1) aliquot to determine Al content: } 2 \times \text { aqua regia until dryness and } 1 \times \mathrm{HNO}_{3} \text { until dryness, re- } \\
\text { dissolution in } \mathrm{HNO}_{3} \text { for ICP-OES } \\
\text { (2) addition of } \mathrm{H}_{2} \mathrm{SO}_{4} \text { and evaporation at } 150{ }^{\circ} \mathrm{C} \text { until only } \mathrm{H}_{2} \mathrm{SO}_{4} \text { left, transfer into Platinum dish } \\
\text { evaporation at } 450{ }^{\circ} \mathrm{C} \text { until dryness } \\
\text { (3) Re-dissolution in } \mathrm{HNO}_{3}\end{array}$ \\
\hline 3.1 & Selective precipitation & $\begin{array}{l}\text { (1) Removal of } \mathrm{Fe}, \mathrm{Ti} \text { at high } \mathrm{pH} \text { in } \mathrm{NaOH} \\
\text { (2) Precipitation of } \mathrm{Be} \text { and } \mathrm{Al} \mathrm{pH} 8 \text {, removal of } \mathrm{Ca} \text { and } \mathrm{Na} \text { using } \mathrm{NH}_{3 \mathrm{aq}}\end{array}$ \\
\hline 3.2 & Ion exchange and sample purification & $\begin{array}{l}\text { Dissolution of hydroxide precipitate in oxalic acid, pre-packed anion and cation chromatography } \\
\text { columns stacked (BIO-RAD Poly-Prep@ prefilled, AG } 50 \mathrm{~W}-\mathrm{X} 8 \text { and AG 1-X8, both 100-200 } \\
\text { mesh) } \\
\text { (1) Adsorb Be onto cation column and remove with } 1.2 \mathrm{M} \mathrm{HCl} \\
\text { (2) Desorb } \mathrm{Al} \text { from anion column onto cation column } \\
\text { (3) Elute } \mathrm{Al} \text { from cation column with } 2.5 \mathrm{M} \mathrm{HCl} \\
\text { (4) Precipitate both ions as hydroxides and wash gels in pH } 7 \text { pure water (removal of salts) }\end{array}$ \\
\hline 3.3 & Ignition & In muffle furnace at $900{ }^{\circ} \mathrm{C}$ for $\mathrm{Be}$ and at $1000{ }^{\circ} \mathrm{C}$ for $\mathrm{Al}$ \\
\hline 4 & Preparation of AMS measurement & $\begin{array}{l}\text { For batch KNG1 both oxide powders were mixed with } \mathrm{Nb} \text { binder and for KNG2 and } 3 \text { both with } \mathrm{Cu} \\
\text { binder }\end{array}$ \\
\hline
\end{tabular}

are extracted and purified by using a combination of ion exchange chromatography and $\mathrm{pH}$ selective precipitation.

During the last steps of sample processing hydroxides are converted into metal oxides $\left(\mathrm{BeO}\right.$ and $\left.\mathrm{Al}_{2} \mathrm{O}_{3}\right)$ and targets for AMS measurement are prepared to determine their ${ }^{10} \mathrm{Be} /{ }^{9} \mathrm{Be}$ and ${ }^{27} \mathrm{Al} /{ }^{26} \mathrm{Al}$ ratios.

The samples were processed following the $\mathrm{MH}$ and KNG procedures (Tables 1 and 2, respectively). In addition, the reduced $\mathrm{MH}$ protocol, without the fluoride conversion step using $\mathrm{HClO}_{4}$ (step 2.3.2. in Table 1) was tested on all samples (MH1 and MH2 sample batches, Tables S 2 and S4,). This simplification is resulting in a faster, more simple evaporation procedure. However, when omitting the step of breaking up the insoluble metal fluorides, the samples are more prone to the formation of a fluoride precipitate during evaporation.

In case a substantial, light-greyish-yellow precipitate formed during the evaporation of the $\mathrm{HF}-\mathrm{HNO}_{3}$ solution to dryness (Dan14-12, -13, -14; -21 and -22 in MH1 and $\mathrm{MH} 2$ batches of simplified protocol), the addition of nitric acid and further heating was not sufficient to re-dissolve this precipitate. Therefore, the clear supernatant solution was transferred into centrifuge tubes and the precipitate was rinsed twice with $7.1 \mathrm{M} \mathrm{HCl}$ and once with $\mathrm{H}_{2} \mathrm{O}$ and left in the PTFE beakers. To ensure that no precipitate was transferred, the solute was centrifuged, rinsed again, 2 times with 7.1 $\mathrm{M} \mathrm{HCl}$, once with $\mathrm{H}_{2} \mathrm{O}$ and the clear supernatant was transferred into a new tube. This clear solution was further processed (Figs. 3, 4).

The main goal of this test was threefold: (1) to test the performance of the faster protocol (2) to investigate the effect of the insoluble precipitates on the calculated ${ }^{26} \mathrm{Al}$ and ${ }^{10} \mathrm{Be}$ concentrations of the samples; (3) to reveal if $\mathrm{Be}$ or $\mathrm{Al}$ are trapped linearly, or $\mathrm{Be}$ is not sensitive to precipitate formation, as it was suggested for fluoride precipitates formed during feldspar digestion and evaporation [18].

All the samples where fluoride precipitate was formed using the simplified protocol were re-processed using the full protocol (except for Dan14-14, see the Aluminium-26 results section, Table 3 ). ${ }^{10} \mathrm{Be}$ and ${ }^{26} \mathrm{Al}$ concentrations of both sub-samples were determined in order to quantify the effect of $\mathrm{Al}$ and Be trapping in the insoluble fluorides. A control sample (Dan14-23) with no precipitate formation in the simplified protocol was also re-processed. Then the 

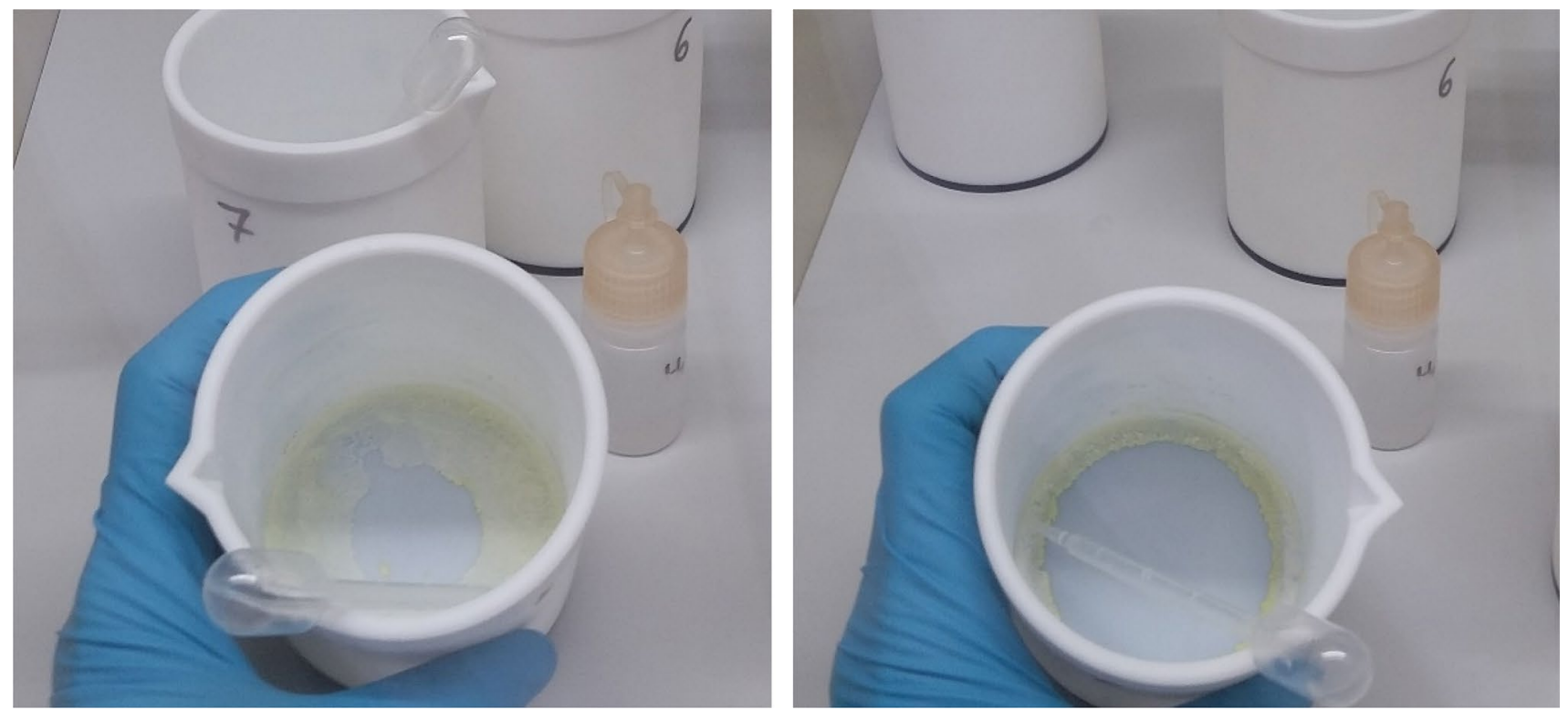

Fig. 3 Insoluble fluoride precipitates in the PTFE beakers after evaporation of the digested samples to dryness (left: Dan14-12, right: Dan14-14)
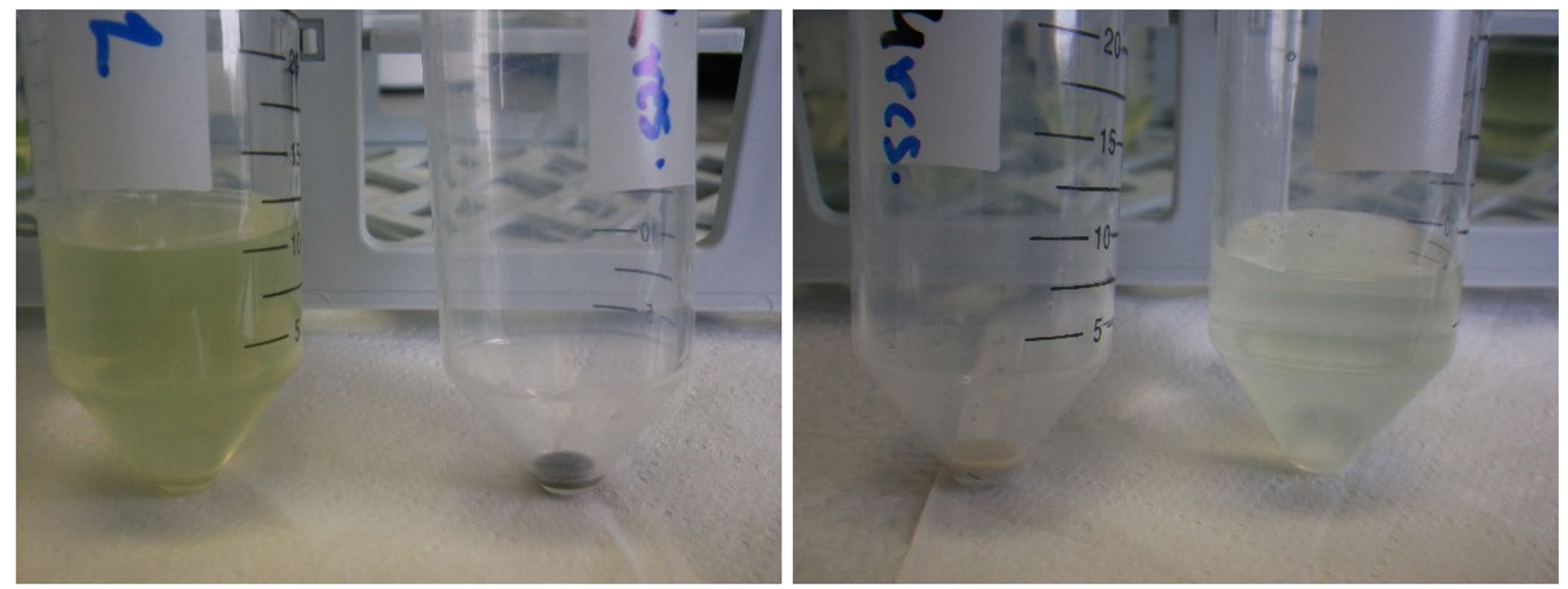

Fig. 4 Insoluble fluoride precipitates in centrifuge tubes after rinsing and centrifuging and the clear supernatant transferred to a new tube. This solute was used for ion exchange (left: Dan14-12, right: Dan14-14)

resulting ${ }^{10} \mathrm{Be}$ and ${ }^{26} \mathrm{Al}$ concentrations were compared to each other and to the assays processed using the full KNG protocol.

It has to be emphasized that the quality of the purified quartz is of major importance for several reasons:

i) as it has been mentioned above, the production of ${ }^{10} \mathrm{Be}$ and ${ }^{26} \mathrm{Al}$ have been calibrated within quartz only and therefore the presence of other minerals with different production rates of ${ }^{10} \mathrm{Be}$ and ${ }^{26} \mathrm{Al}$ (as they may have different amount of target elements such as $\mathrm{O}, \mathrm{Si}, \mathrm{Al}$ ) will lead to a bias during the determination of the production time span;

ii) presence of Al-bearing minerals and impurities within the quartz during the evaporation step after HF digestion may produce huge precipitates that retain $\mathrm{Al}$, and make it impossible to determine the correct amount of ${ }^{27} \mathrm{Al}$ necessary to calculate the ${ }^{26} \mathrm{Al}$ amount after AMS measurement. Fortunately, according to a previous study where precipitates formed during feldspar digestion were tested, $\mathrm{Be}$ is not most probably not affected by the presence of these precipitates [18]. 
Table 3 Summary table of sample description and processed sample aliquots. Numbers in parenthesis means that the sample was processed but gave no AMS current for Al. *Reference material described by Binnie et al. [9]. **Three aliquots for both nuclides and two aliquots for ${ }^{10} \mathrm{Be}$ only. (1) means that the assay was done, but gave no current during AMS

\begin{tabular}{lllll}
\hline & Material & \multicolumn{2}{l}{ Protocol } & \\
\cline { 3 - 5 } & & MH & & KNG \\
\cline { 3 - 4 } & & Simplified & Full & Full \\
\hline Dan 14-10 & quartz cobble, (bluish polycrystalline vein quartz) & 1 & 1 & 1 \\
Dan 14-11 & quartz cobble (unspecific) & $(1)$ & 1 & 1 \\
Dan 14-12 & quartz cobble (metamorphic cobble, showing foliation) & 1 & - & 1 \\
Dan 14-13 & quartz cobble (metamorphic) & 1 & 1 & 1 \\
Dan 14-14 & quartz cobble (metamorphic with foliation, porphyoblasts) & 1 & - & - \\
Dan 14-15 & quartz cobble (unspecific) & $(1)$ & 1 & 1 \\
Dan 14-20 & quartz cobble (unspecific) & 1 & 1 & - \\
Dan 14-21 & quartz cobble (quartzite) & 1 & 1 & - \\
Dan 14-22 & quartz cobble (unspecific) & 1 & 1 & 1 \\
Dan 14-23 & quartz cobble (vein quartz) & 1 & 1 & 1 \\
Dan 14-24 & quartz cobble (fine-grained) & 1 & - & 1 \\
Dan 14-25 & quartz cobble (possibly vein quartz) & 1 & - & - \\
CoQtz-N & reference material* & 0 & 3 & $3+2^{* *}$ \\
\hline
\end{tabular}

iii) in samples with high ${ }^{27} \mathrm{Al}$ content it may be problematic to obtain a perfect separation of Be and Al during the ion exchange chromatography. The presence of $\mathrm{Al}$ in $\mathrm{BeO}$ will alter the emission current when performing the AMS measurement and may thus results in a lower counting statistics. In such cases the use of multiple cationic exchange resin steps and/or larger ion exchange columns may help reducing the ${ }^{27} \mathrm{Al}$ content in the $\mathrm{BeO}$ target [19?].

It has to be noted that the CoQtz-N reference material was purified quartz [9], therefore it was used without any quartz purification steps (processed from steps 2.1 onwards in Tables 1, 2).

The main differences between the chemical sample processing are

i) The method of quartz cleaning,

ii) The timing of carrier addition and determination of $\mathrm{Al}$ content in an aliquot,

iii) The sample dissolution temperature,

iv) The agent used to convert metal-fluorides into soluble form,

v) The ion exchange column types and volumes,

vi) The timing of $\mathrm{pH}$ selective precipitation.

\section{Determination of the ${ }^{27} \mathrm{Al}$ concentration}

It is essential to know the exact amount of $\mathrm{Al}$ in the dissolved sample for the calculation of its ${ }^{26} \mathrm{Al}$ concentration. For this purpose, an aliquot must be taken from the solution and its Al concentration was determined using Inductively
Coupled Plasma Mass Spectrometry (Agilent ICP-MS 7500 at the Geological Survey of Austria, Vienna), Inductively Coupled Plasma-Optical Emission Spectrometry (ICP-OES; ICAP 6500 from Thermo at CEREGE, Aix en Provence, France; and a Perkin Elmer Optima 8300 ICP-OES at BOKU, Vienna, Austria) and Microwave Plasma - Atom Emission Spectrometry (Agilent $4100 \mathrm{MP}-\mathrm{AES}$ at the Institute of Nuclear Research, Debrecen, Hungary). As MP-AES is not as widely used for the determination of the stable (natural, native) Al content of samples, therefore for some samples the native Al content was determined using both the ICP-OES and MP-AES methods, in order to test the accuracy and precision of this method.

\section{Accelerator mass spectrometry measurements}

AMS measurements were performed at ASTER, the French national facility, CEREGE, Aix en Provence [19] and at VERA, Vienna Environmental Research Accelerator, Faculty of Physics, University of Vienna.

At ASTER BeO was mixed with Niobium powder in $\mathrm{Cu}$ cathodes. Samples were normalized to the standard STD11 with an assigned ${ }^{10} \mathrm{Be} /{ }^{9} \mathrm{Be}$ ratio of $(1.191 \pm 0.013) \times 10^{-11}$ [20]. Aster terminal voltage is set at $4.5 \mathrm{MV}^{-\mathrm{BeO}^{-}}$is stripped to $\mathrm{Be}^{2+}$ within the terminal (stripper gas is Argon at $1.2 \times 10^{-2}$ $\mathrm{mBar}$ ) then to $\mathrm{Be}^{4+}$ after the absorber foil ( $\mathrm{SiN}$ ) used to separate $\mathrm{Be}$ from $\mathrm{B}$ [19]. At VERA, samples were normalized to the standard SMD-Be-12 [21]. Both standards are comparable with KNSTD [22] with a ${ }^{10}$ Be half-life of 1.387 Myr. The uncertainty of the reference material is included in the reported uncertainties. At VERA ${ }^{10} \mathrm{Be}$ was measured using isobar suppression with a foil stack absorber [23] technique. At the maximum terminal voltage of $3 \mathrm{MV}$ and an argon 
stripper areal density of $\sim 4 \mu \mathrm{g} / \mathrm{cm}^{2}$ this detection method allows the high energy beam of ${ }^{10} \mathrm{Be}^{2+}$ to impact on the absorber foils and the directly following gas-filled ionization chamber. Depending on the ${ }^{10} \mathrm{~B}$ and ${ }^{9} \mathrm{BeH}$ content of each sample the detector electronics may have to process additional events, produced by ions which were not stopped or even created in nuclear reactions in the $\mathrm{SiN}$ foils. These events can be separated from the ${ }^{10} \mathrm{Be}$ by their energy loss in the detector volume but need to be considered for a correct live time estimation of the measurement. In this study, this showed to be a particular requirement and was guaranteed by an electronic pulser module producing 70 artificial counts per second.

${ }^{26} \mathrm{Al}$ samples measured at ASTER (extracted as $\mathrm{Al}^{-}$and measured under the $\mathrm{Al}^{3+}$ form) were normalized to the standard SM-Al-11 with a ${ }^{26} \mathrm{Al} /{ }^{27} \mathrm{Al}$ ratio of $(7.401 \pm 0.064) \times 10^{-12}$ with a terminal voltage set at 2.7 MV [19], and those measured at VERA were normalized to SMD-Al-11. Both are secondary standard materials directly traceable to primary standards [19, 24, 25]. At VERA ${ }^{26} \mathrm{Al}$ is measured with the ILIAMS method [26] where an $\mathrm{AlO}^{-}$beam is injected into a radiofrequency quadrupole and overlapped with a laser beam. With this technique, the interfering isobar $\mathrm{MgO}^{-}$can be suppressed by 14 orders of magnitude, resulting in machine blank levels of $5 \cdot 10^{-16}$. The ${ }^{26} \mathrm{Al}$ ions are counted in a gas-filled ionization chamber in the charge state $3+$ to avoid interferences from ${ }^{13} \mathrm{C}^{1+}$. The maximum yield for the $3+$ state was found for argon stripping at 2.9 MV with a stripper gas density of $\sim 3 \mu \mathrm{g} / \mathrm{cm}^{2}$. Since the stripper gas pressure measurement at the terminal is technically challenging and the density profile in the tube is generally unknown, the areal density for the stripper gas at VERA can only be estimated.

At ASTER, both $\mathrm{Be}$ and $\mathrm{Al}$ samples are measured three times for 20 min divided in 40 blocks of $30 \mathrm{~s}$ each. At the end of the batch, for a given sample, these three measurements are compared and recombined to provide the ${ }^{10} \mathrm{Be} /{ }^{9} \mathrm{Be}$ or ${ }^{26} \mathrm{Al} /{ }^{27} \mathrm{Al}$ measured ratios. Uncertainties are taking into account the counting statistics of each sample, the standard variability within the entire batch, the standard uncertainties and for ${ }^{10} \mathrm{Be}$ a $0.5 \%$ external uncertainty [19].

\section{Results}

\section{Beryllium-10 results}

Beryllium results are presented in Supplementary Tables $\mathrm{S} 1$ and S2. With the $\mathrm{MH}$ protocol, the measured ${ }^{10} \mathrm{Be} /{ }^{9} \mathrm{Be}$ ratio of the samples varied between $(1.54 \pm 0.06) \mathrm{E}-13$ and $(2.76 \pm 0.19) \mathrm{E}-14$ for the natural (Haslau) samples and between $(8.59 \pm 0.19) \mathrm{E}-13$ to $(7.22 \pm 0.27) \mathrm{E}-13$ for the reference material (CoQtz-N) assays. With the KNG protocol, the ${ }^{10} \mathrm{Be} /{ }^{9} \mathrm{Be}$ ratio of the Haslau samples was between $(2.84 \pm 0.06) \mathrm{E}-13$ and $(4.17 \pm 0.18) \mathrm{E}-14$ and between $(6.59 \pm 0.32) \mathrm{E}-13$ and $(8.59 \pm 0.19) \mathrm{E}-13$ for the CoQtz-N samples. The mean ${ }^{10} \mathrm{Be} /{ }^{9} \mathrm{Be}$ ratio of the process blanks was $(5.06 \pm 0.90) \mathrm{E}-15$ and $(3.33 \pm 0.66) \mathrm{E}-15$ with the $\mathrm{MH}$ and $\mathrm{KNG}$ protocols, respectively. The analytical uncertainties of the ${ }^{10} \mathrm{Be} /{ }^{9} \mathrm{Be}$ ratios of the samples had a mean of 5.1 and $5.7 \%$ for the $\mathrm{MH}$ and $\mathrm{KNG}$ protocols. The reported uncertainties include the ${ }^{9} \mathrm{Be}$ carrier concentration, weighing and the AMS measurements (including the process blanks) and standards' uncertainties.

The ${ }^{10} \mathrm{Be}$ concentrations of the CoQtzMH assays and of 4 out of 5 CoQtzKNG assays were identical within $1 \sigma$ uncertainties with the reference value [9] (Fig. 5A). The

${ }^{10} \mathrm{Be}$ concentration measured for the CoQtzKNG-17 assay is $11 \%$ lower than the reference value, being just out of the $1 \sigma$ confidence interval. All ${ }^{10} \mathrm{Be}$ concentrations of duplicate samples from the Haslau quarry processed using the $\mathrm{MH}$ protocol are in good agreement with each other and overlap with the results of the assays processed using the KNG scheme within $2 \sigma$. (Table S1; Fig. 6).

\section{Aluminium-26 results}

Aluminium concentrations are listed in Supplementary Tables S3 and S4. For assays of the Haslau samples processed using the $\mathrm{MH}$ scheme, the measured ${ }^{26} \mathrm{Al} /{ }^{27} \mathrm{Al}$ ratio varied between $(2.98 \pm 1.66) \mathrm{E}-13$ and $(1.71 \pm 0.0 .30) \mathrm{E}-14$ and from $(2.81 \pm 0.07) \mathrm{E}-12$ to $(2.49 \pm 0.14) \mathrm{E}-12$ for the CoQztMH assays. The Haslau samples processed using the KNG protocol had a ratio from $(4.74 \pm 0.20) \mathrm{E}-13$ to $(2.73 \pm 0.28) \mathrm{E}-14$, and the CoQtzKNG samples were between $(1.89 \pm 0.09) \mathrm{E}-12$ and $(2.13 \pm 0.07) \mathrm{E}-12$. The reported uncertainties of the ${ }^{26} \mathrm{Al}$ concentrations include ${ }^{27} \mathrm{Al}$ carrier concentration as given on certificate, weighing, measurement of the total $\mathrm{Al}$ content and the analytical uncertainties of AMS measurements and standards including the process blanks. The mean ${ }^{26} \mathrm{Al} /{ }^{27} \mathrm{Al}$ ratio of the blanks of the MH protocol was $(7.05 \pm 2.41) \mathrm{E}-15$. For batches MH1, MH3 and MH4 the ${ }^{26} \mathrm{Al} /{ }^{27} \mathrm{Al}$ ratio of the process blanks was below the detection limit and the sample ratios were corrected with the machine blanks. The mean blank ratio for the KNG samples was $(8.27 \pm 6.39)$ E-16. The Blk ratio of the KNG2 batch was zero, therefore this sample was not blank corrected. The mean analytical uncertainty of the samples was $11 \%$ for the MH samples (excluding the unusually high 56\% value of the Dan14-10 sample due to low current at AMS) and 9\% for the KNG scheme.

The ${ }^{26} \mathrm{Al}$ concentrations of two out of the three CoQtzMH samples were at the reference value [9], while one sample 

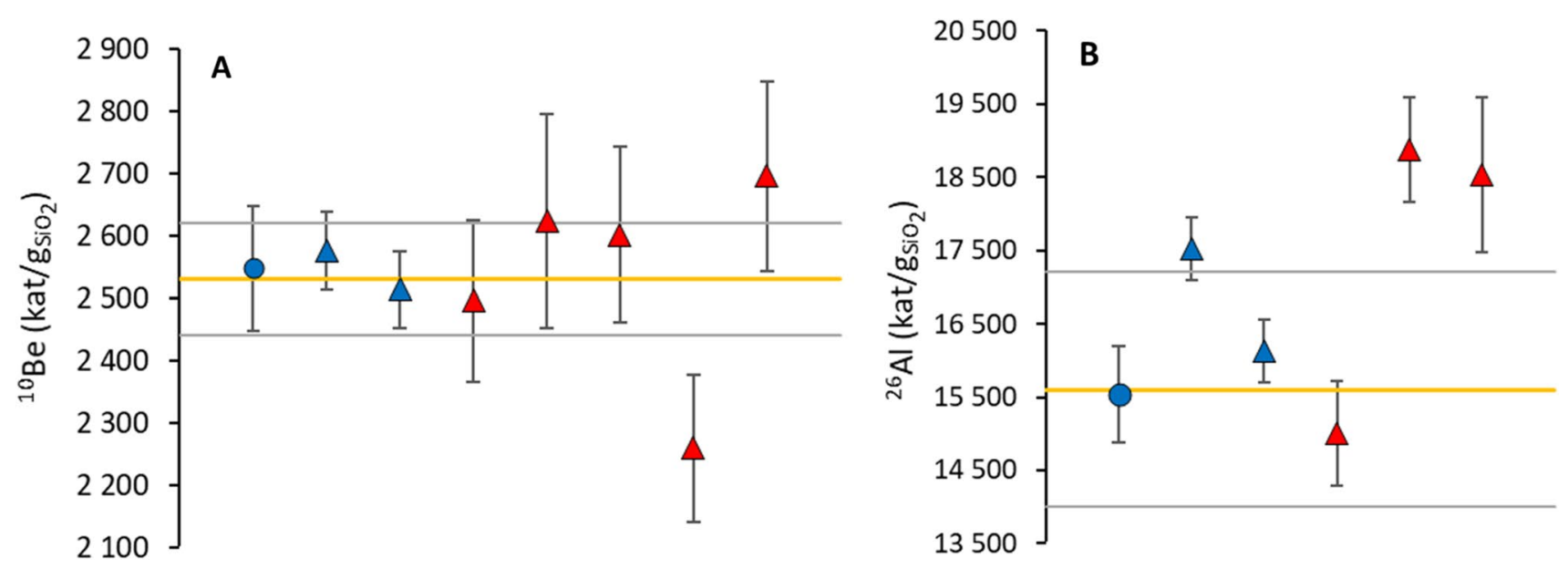

Fig. $5{ }^{10} \mathrm{Be}(\mathrm{A})$ and ${ }^{26} \mathrm{Al}(\mathrm{B})$ concentrations of the CoQtz-N samples with $1 \sigma$ uncertainty. Colours mean assays processed using the $\mathrm{MH}$ (blue) and KNG (red) schemes. The shape of the symbols refers to the AMS facility, dots: ASTER, triangles: VERA. The yellow and

(CoQtz-N-Bp19/1) was slightly higher, but still in agreement within $1 \sigma$ uncertainty (Fig. 5B, Table S4). The ${ }^{26} \mathrm{Al}$ concentrations calculated using the native $\mathrm{Al}$ concentrations determined either by ICP-OES or MP-AES agreed within error (as described in the Discussion) and the weighted mean of the two ${ }^{26} \mathrm{Al}$ values was used for the comparison to the reference value. The ${ }^{26} \mathrm{Al}$ concentration of the CoQtzKNG17 sample was matching the reference value, and the CoQtzKNG15 and -16 values were slightly higher (21\% and $18 \%$, respectively) just outside the $1 \sigma$ uncertainty range (Fig. 5B).

At first glance the ${ }^{26} \mathrm{Al}$ concentrations of the samples show a puzzling picture where different assays of some samples are matching (Dan14-10, -11, -15, -23), while others are considerably lower than their duplicate(s) (Dan14-12, $-13,21,-22$ ) (Table S4, Fig. 7). The samples with the low concentrations that do not match their pairs are coincident with the assays that were affected by the formation of a visible precipitate after evaporation using the simplified $\mathrm{MH}$ procedure.

The precipitates were examined using X-Ray Diffraction (XRD) at the Geological and Geochemical Research Institute in Budapest (Rigaku Miniflex 600 X-Ray Diffractometer, $\mathrm{Cu} \mathrm{K} \alpha$ radiation, $40 \mathrm{kV}, 20 \mathrm{~mA}$ ) and in most cases proved to be Aluminium-fluorides and in some cases, also contained insoluble minerals of metamorphic origin like pyrophyllite (Dan14-12), zircon (Dan14-12, -13) or kyanite (Dan14-14).

The alumosilicate kyanite was also independently detected in the Vienna sub-sample of Dan14-14 by XRD at the Clay Mineralogical Laboratory of the Institute of Applied Geology (Panalytical X'Pert PRO diffractometer, $\mathrm{Cu} \mathrm{K} \alpha$ radiation, $40 \mathrm{kV}, 40 \mathrm{~mA}$ ). This sample was then

black lines are the reference values and their uncertainties (95\% confidence limits) from Binnie et al. [9]. For data refer to Tables S1 and S3. (Color figure online)

skipped as the hot $\mathrm{H}_{2} \mathrm{SO}_{4}$ digestion most likely dissolved kyanite and in this way added unaccounted $\mathrm{Al}$ to the sample.

\section{Discussion}

\section{Well-matching Beryllium-10 records-no risk of Beryllium loss due to fluoride precipitate}

The different protocols regarding total digestion, purification, and chromatography resulted in consistent ${ }^{10} \mathrm{Be}$ concentrations for the Haslau samples and for the CoQtz-N reference material. The latter originates from a surface sample [9], thus it has considerably higher CRN concentration per $\mathrm{g}$ quartz compared to the Haslau samples. The well-matching ${ }^{10} \mathrm{Be}$ concentrations of the sample duplicates processed via the simplified and the full protocol imply a correct ${ }^{10} \mathrm{Be}$ determination. The reported full-process blank ${ }^{10} \mathrm{Be} /{ }^{9} \mathrm{Be}$ ratios ensure that the background at both facilities involved in the study is low enough to deliver reliable and repeatable data. All ${ }^{10} \mathrm{Be}$ concentrations overlap within error (Fig. 6). Accordingly, our results are in accordance with [18] suggesting that ${ }^{10} \mathrm{Be}$ concentrations are unaffected by the fluoride precipitates and robust even in case some precipitate was formed during its evaporation to dryness.

\section{Fluoride precipitate as a potential trap of Aluminium}

The ${ }^{26} \mathrm{Al} /{ }^{27} \mathrm{Al}$ ratios of the full-process blanks were low enough to guarantee that the background at both facilities 
Fig. 6 Kernel density estimate plots of ${ }^{10} \mathrm{Be}$ concentrations of double or triple processed samples. Colours refer to the sample processing protocol: $\mathrm{MH}$ : blue, KNG: red. Continuous lines indicate AMS measurement at ASTER, dashed lines are measurements at VERA. For data refer to Tables 3 and $S 2$. The sample-codes in boxes refer to assays containing visible fluoride precipitate at evaporation to dryness with the simplified protocol. As it is demonstrated by the plot, the precipitate did not affect the final ${ }^{10} \mathrm{Be}$ concentrations. (Color figure online)
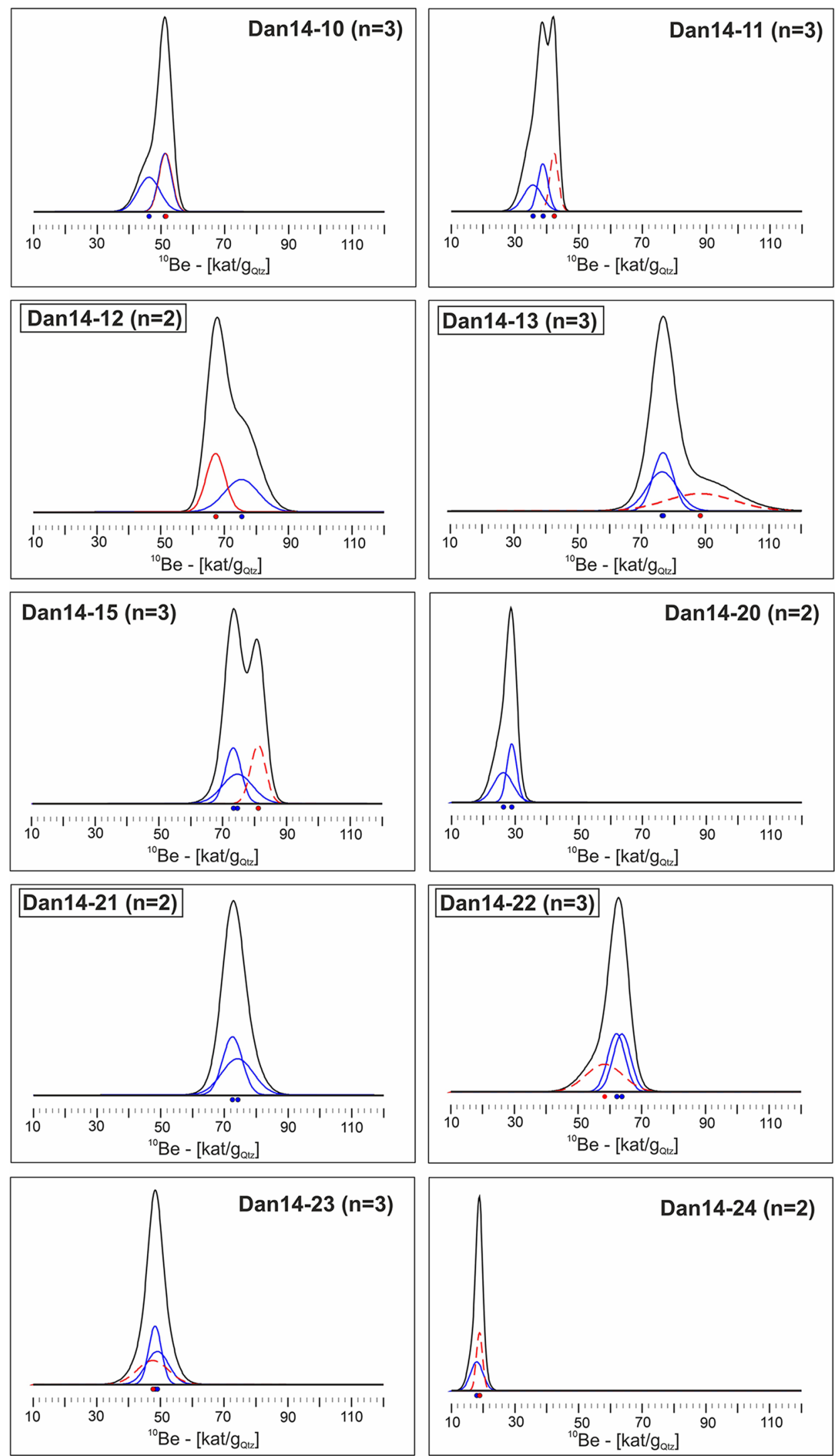
Fig. 7 Kernel density estimate plots of the ${ }^{26} \mathrm{Al}$ concentrations of double or triple processed samples. Colours refer to the sample processing protocol: MH: blue, KNG: red. Continuous lines indicate AMS measurement at ASTER, dashed lines are measurements at VERA. For data refer to Tables 3 and S4. The samplecodes in boxes refer to assays containing visible fluoride precipitate at evaporation to dryness with the simplified protocol ( $p r$.$) . As it is dem-$ onstrated by the plot, the ${ }^{26} \mathrm{Al}$ concentrations of the assays affected by the precipitate are considerably lower compared to their duplicates devoid of precipitate. The ${ }^{26} \mathrm{Al}$ concentration of KNG-Dan14-13 coincident with the MH assay affected by precipitate formation suggests $\mathrm{Al}$ loss of the KNG assay, as well. (Color figure online)
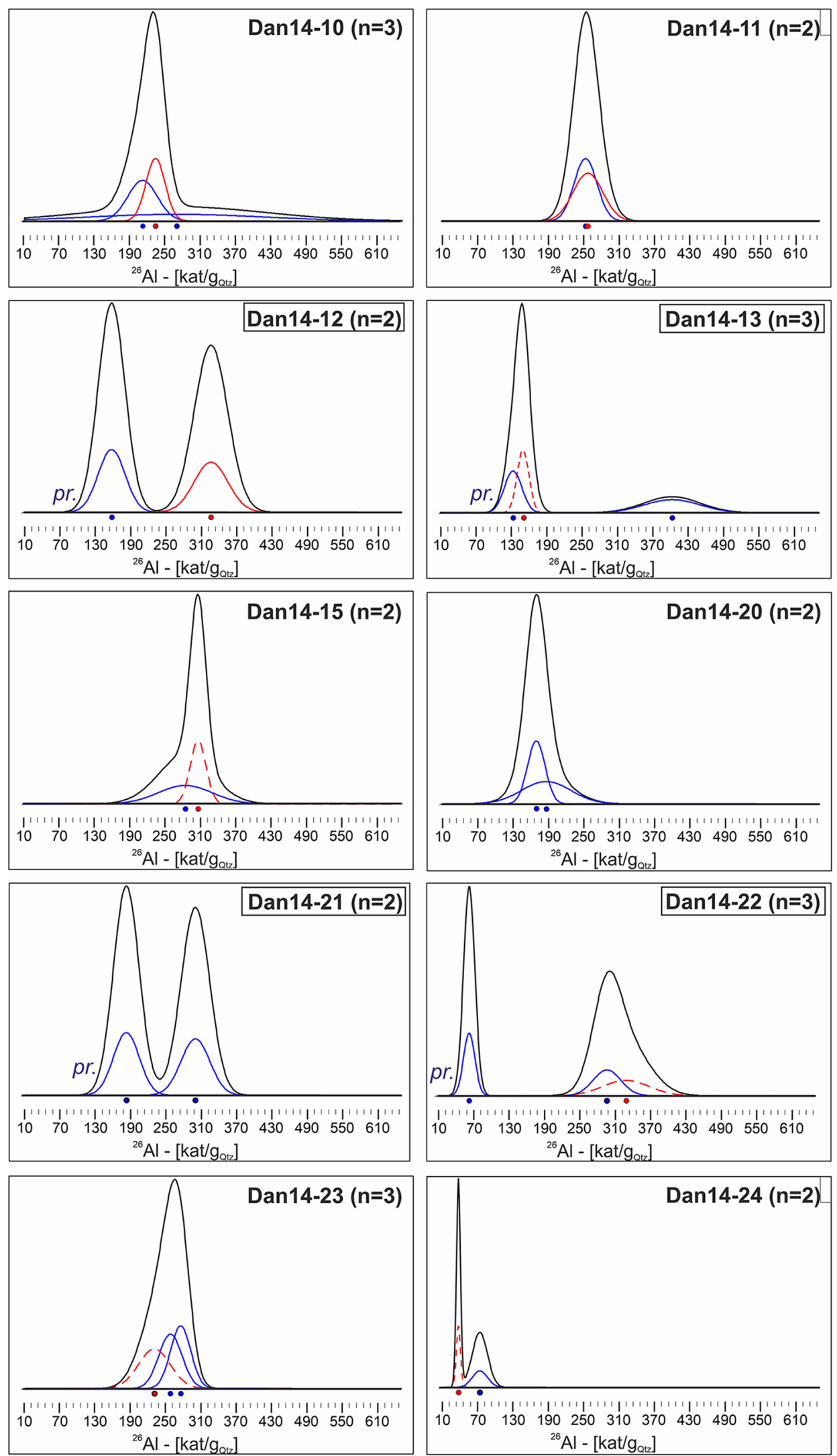

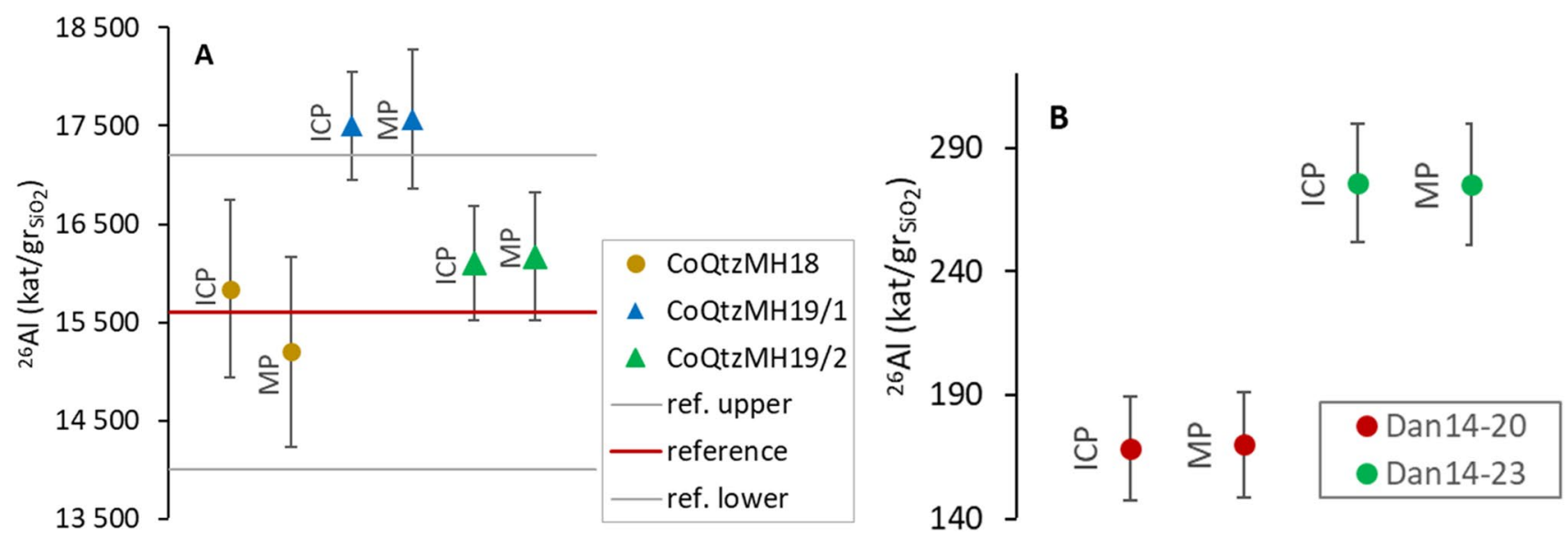

Fig. 8 Comparison of the ${ }^{26} \mathrm{Al}$ concentrations in quartz for subsamples where the total Aluminium content was measured by ICP-OES and MP-AES. A: in the CoQtz-N assays, B: in the Haslau assays. All assays were processed using the full $\mathrm{MH}$ scheme. The shape of the

was low enough to deliver reliable and repeatable data. During evaporation of the $\mathrm{HF}-\mathrm{HNO}_{3}$ solution (step 2.3 in Tables 1,2) insoluble fluoride precipitate was formed in several samples when using the simplified MH protocol. All samples affected by visible fluoride precipitate, were also processed using the full $\mathrm{MH}$ protocol, except for the problematic Dan14-14 (Tables 3 and S4). The full protocol involves addition of $5 \mathrm{ml} \mathrm{HClO}_{4}(70 \%)$ to break up metalfluorides converting them into soluble metal-chlorides (Table 1). Using the full-protocol all samples were devoid of fluoride precipitation, except for Dan14-12. Due to the persistent presence of fluoride precipitates, this sample was not further processed using the MH scheme.

${ }^{26} \mathrm{Al}$ concentrations of the full protocol sub-samples were considerably higher compared to those processed via the simplified protocol. The assays unaffected by fluoride precipitates had similar concentrations, regardless of the protocol used for their processing (Table S4 and Fig. 7). This suggests that if the fluoride precipitate was not formed or it was successfully broken up by $\mathrm{HClO}_{4}$ addition, all $\mathrm{Al}$ was available in soluble chloride form and no loss of $\mathrm{Al}$ occurred. Accordingly, the in the absence of fluoride precipitates after evaporation duplicate samples provide comparable and repeatable results.

The only outlier is sample KNG3-Dan14-13 (Fig. 7). Al concentrations in sample splits processed using the simplified and full $\mathrm{MH}$ protocols follow the expected trend: the $133 \pm 49 \mathrm{~kat} / \mathrm{g}_{\mathrm{SiO} 2}$ increased to $409 \pm 48 \mathrm{~kat} / \mathrm{g}_{\mathrm{SiO} 2}$ when no fluoride precipitates were formed. Surprisingly, the ${ }^{26} \mathrm{Al}$ concentration of the KNG assay resulted in $147 \pm 10 \mathrm{~kat} /$ $\mathrm{g}_{\mathrm{SiO} 2}$ (mean of two measured targets), and is thus similar to the MH sub-sample affected by Al loss even though no precipitation was observed. The KNG3-Dan14-13 sample also had a higher ${ }^{10} \mathrm{Be}$ value (Fig. 6), therefore this assay is most symbols refers to the AMS facility, dots: ASTER, triangles: VERA. The reference value is from Binnie et al. [9]. For data refer to Tables $\mathrm{S} 3$ and $\mathrm{S} 4$

likely an analytical outlier for both $\mathrm{Al}$ and $\mathrm{Be}$ concentrations for the KNG scheme.

Generally, fluoride precipitates are more prone to form in samples with high natural $\mathrm{Al}$ content (Table S4). Excess Al might be present in a sample if the purified quartz contains traces of Al-bearing minerals (e.g. feldspars, mica). In some cases, it might be present in the quartz lattice itself [27]. Accordingly, the thorough cleaning of quartz must be the first step in preventing fluoride precipitation, followed by breaking up any fluorides that might happen to form during sample dissolution and evaporation [6].

\section{Comparison of ICP-OES and MP-AES for the determination of the ${ }^{27} A$ l concentration}

In five samples (three CoQtzMH assays and samples: MH3Dan 14-20 and -23, the native Al concentration was determined by both ICP-OES and MP-AES (Tables S3 and S4). The $\mathrm{Al}$ concentrations determined by ICP and the MP were consistent within 1-7\%. This translates to a final difference of $1-4 \%$ for the ${ }^{26} \mathrm{Al}$ results. (Fig. 8A, B).

Obviously, the measured $\mathrm{Al}$ content has a larger effect on samples with high natural Al content. Samples with low native $\mathrm{Al}$ content (like the CoQtz-N samples) are less affected by the result of the measured native $\mathrm{Al}$ concentration, as the carrier added contributes the major part of the total $\mathrm{Al}$ content of these samples. In addition, aliquots with high Al concentration must be more diluted before ICP or MP measurements, which is also a potential source of error. These facts call attention to the importance of reduction of natural $\mathrm{Al}$ in the quartz separate as much as possible by thorough purification of quartz. 


\section{Conclusions}

Two different sample processing protocols $\mathrm{KNG}$ and $\mathrm{MH}$ (Kohl and Nishiizumi [7] updated by Granger et al. [8] and Merchel and Herpers [5]) regarding total digestion, purification, and chromatography followed by two independent cosmogenic nuclide sample preparation facilities resulted in consistent ${ }^{10} \mathrm{Be}$ and ${ }^{26} \mathrm{Al}$ concentrations.

Formation of insoluble fluoride precipitate during sample digestion and evaporation may lead to considerable loss of $\mathrm{Al}$ and lowered ${ }^{26} \mathrm{Al}$ concentrations. Therefore, the addition of a strong oxidizing agent, such as $\mathrm{HClO}_{4}$ or $\mathrm{H}_{2} \mathrm{SO}_{4}$ at the end of sample evaporation to break up fluorides is strongly recommended. The use of ${ }^{26} \mathrm{Al}$ concentrations of samples that were affected by fluoride precipitation is not possible for geochronological purposes. Samples with high natural Al content are more prone to fluoride precipitation, therefore we emphasize the need for a thorough quartz purification before the extraction of in-situ produced cosmogenic $\mathrm{Al}$ from the crystal lattice to minimise the natural $\mathrm{Al}$ content of the samples.

Our experiment demonstrated that ${ }^{10} \mathrm{Be}$ concentrations are unaffected by the fluoride precipitates and thus ${ }^{10} \mathrm{Be}$ concentrations can be used with confidence even for these problematic samples.

Additionally, the parallel measurement of natural Al concentrations by MP-AES and ICP-OES provided similar results suggesting that both methods are suitable for the determination of the total $\mathrm{Al}$ content of the samples.

Supplementary Information The online version contains supplementary material available at https://doi.org/10.1007/s10967-021-07916-4.

Acknowledgements The presented research was supported by the projects NKFIH 124807; OMAA 90öu17, 98 öu17 and Erasmus plus. The measurements performed at the ASTER AMS national facility (CEREGE, Aix en Provence) were supported by the INSU/CNRS, the French Ministry of Research and Higher Education, IRD and CEA. Measurements of CoQtzMH assays performed at VERA were supported by the Radiate Transnational Access 19001688-ST. We are indebted to Attila Demény for his support of the launching and setup of the Cosmo-lab in Budapest. We are grateful to Silke Merchel, Greg Chmiel and Tom Clifton for their useful advice on chemistry and laboratory setup, to Marcel Hirsch for the ICP-OES measurements at BOKU, to Máté Szabó for the XRD measurements, and for István Hegyi for his help in solving any unexpected laboratory issues. Stefanie Maierhofer helped with the section in Fig 1. Three anonymous Reviewers are acknowledged for their constructive comments.

ASTER Team Didier Bourlès, Georges Aumaître, Karim Keddadouche.

Funding Open access funding provided by ELKH Research Centre for Natural Sciences.

Open Access This article is licensed under a Creative Commons Attribution 4.0 International License, which permits use, sharing, adaptation, distribution and reproduction in any medium or format, as long as you give appropriate credit to the original author(s) and the source, provide a link to the Creative Commons licence, and indicate if changes were made. The images or other third party material in this article are included in the article's Creative Commons licence, unless indicated otherwise in a credit line to the material. If material is not included in the article's Creative Commons licence and your intended use is not permitted by statutory regulation or exceeds the permitted use, you will need to obtain permission directly from the copyright holder. To view a copy of this licence, visit http://creativecommons.org/licenses/by/4.0/.

\section{References}

1. Gosse JC, Phillips FM (2001) Terrestrial cosmogenic nuclides: theory and applications: Quat. Sci Rev 20:1475-1560

2. Dunai T (2010) Cosmogenic nuclides: principles, concepts, and applications in the earth surface sciences. Cambridge University Press, New York, $\mathrm{p} 187$

3. Granger DE, Lifton NA, Willenbring JK (2013) A cosmic trip: 25 years of cosmogenic nuclides in geology. GSA Bull 125(9-10):1379-1402

4. Brown ET, Edmond JM, Raisbeck GM, Yiou F, Kurz MD, Brook EJ (1991) Examination of surface exposure ages of Antarctic moraines using in-situ produced ${ }^{10} \mathrm{Be}$ and ${ }^{26} \mathrm{Al}$. Geochim Cosmochim Acta 55:2269-2283

5. Merchel S, Herpers U (1999) An update on radiochemical separation techniques for the determination of long-lived radionuclides via accelerator mass spectrometry. Radiochim Acta 84:215-219

6. Merchel S, Gärtner A, Beutner S, Bookhagen B, Chabilan A (2019) Attempts to understand potential deficiencies in chemical procedures for AMS: Cleaning and dissolving quartz for ${ }^{10} \mathrm{Be}$ and ${ }^{26} \mathrm{Al}$ analysis. Nucl Instr Meth B 455:293-299

7. Kohl CP, Nishiizumi K (1992) Chemical isolation of quartz for measurement of in situ-produced cosmogenic nuclides. Geochim et Cosmochim Acta 56:3583-3587

8. Granger DE, Fabel D, Palmer AN (2001) Pliocene-Pleistocene incision of the Green River, Kentucky, determined from radioactive decay of cosmogenic ${ }^{26} \mathrm{Al}$ and ${ }^{10} \mathrm{Be}$ in Mammoth Cave sediments. GSA Bull 113(7):825-836

9. Binnie SA, Dewald A, Heinze S, Voronina E, Hein A, Wittmann H, Von Blanckenburg F, Hetzel R, Christl M, Schaller M, Léanni L, ASTER Team, Hippe K, Vockenhuber C, Ivy-Ochs S, Maden C, Fülöp RH, Fink D, Wilcken KM, Fujioka T, Fabel D, Freeman SPHT, Xu S, Fifield LK, Akçar N, Spiegel C, Dunai T (2019) Preliminary results of CoQtz-N: a quartz reference material for terrestrial in-situ cosmogenic ${ }^{10} \mathrm{Be}$ and ${ }^{26} \mathrm{Al}$ measurements. Nucl Instr Meth B 456:203-212

10. Lal D (1991) Cosmic ray labeling of erosion surfaces - In situ nuclide production rates and erosion models. Earth Planet Sci Lett 104(2-4):424-439

11. Chmeleff J, von Blanckenburg F, Kossert K, Jakob D (2010) Determination of the ${ }^{10} \mathrm{Be}$ half-life by multicollector ICP-MS and liquid scintillation counting: Nucl. Instr Meth B 268:192-199

12. Korschinek G, Bergmaier A, Faestermann T, Gerstmann UC, Knie K, Rugel G, Wallner A, Dillmann I, Dollinger G, Lierse von Gostomski C, Kossert K, Maiti M, Poutivtsev M, Remmert A (2010) A new value for the half-life of ${ }^{10} \mathrm{Be}$ by heavy-ion elastic recoil detection and liquid scintillation counting. Nucl Instr Meth B 268:187-191

13. Nishiizumi K (2004) Preparation of 26Al AMS standards. Nucl Instr Meth B 223-224:388-392

14. Decker K, Peresson H, Hinsch R (2005) Active tectonics and quaternary basin formation along the vienna basin transform fault. Quat Sci Rev 24(3-4):305-320 
15. Salcher BC, Meurers B, Smit J, Decker K, Hölzel M, Wagreich M (2012) Strike-slip tectonics and Quaternary basin formation along the Vienna Basin fault system inferred from Bouguer gravity derivatives. Tectonics $31(3)$

16. Neuhuber S, Plan L, Gier S, Hintersberger E, Lachner J, Scholz D, Lüthgens C, Braumann SM, Bodenlenz F, Fiebig M (2020) Numerical age dating of cave sediments to quantify vertical movement at the Alpine-Carpathian transition in the Plio- and Pleistocene. Geol Carpathica 71(6):539-557

17. Schnabel W (2002) Geologische Karte von Niederösterreich 1:200 000. Geologische Bundesanstalt, Wien

18. Zerathe S, Blard PH, Braucher R, Bourles D, Audin L, Carcaillet J, Delgado F, Benavente C, Aumaître G, Keddadouche K (2017) Toward the feldspar alternative for cosmogenic ${ }^{10} \mathrm{Be}$ applications. Quat Geochronol 41:83-96

19. Arnold M, Merchel S, Bourlès DL, Braucher R, Benedetti L, Finkel RC, Aumaître G, Gottdang A, Klein M (2010) The French accelerator mass spectrometry facility ASTER: improved performance and developments. Nucl Instrum Methods Phys Res, Sect B Interact Mater Atoms 268(11-12):1954-1959

20. Braucher R, Guillou V, Bourlès DL, Arnold M, Aumaître G, Keddadouche K, Nottoli E (2015) Preparation of ASTER in-house ${ }^{10} \mathrm{Be} /{ }^{9} \mathrm{Be}$ standard solutions. Nucl Instr Meth B 361:335-340

21. Akhmadaliev S, Heller R, Hanf D, Rugel G, Merchel S (2013) The new 6 MV AMS-facility DREAMS at Dresden. Nucl Instr Meth B 294:5-10
22. Nishiizumi K, Imamura M, Caffee MW, Southon JR, Finkel RC, McAninch J (2007) Absolute calibration of ${ }^{10} \mathrm{Be}$ AMS standards. Nucl Instr Meth B 258(2):403-413

23. Steier P, Martschini M, Buchriegler J, Feige J, Lachner J, Merchel S, Milchmayr L, Priller A, Rugel G, Schmidt E, Wallner A, Wild EM, Golser R (2019) Comparison of methods for the detection of ${ }^{10} \mathrm{Be}$ with AMS and a new approach based on a silicon nitride foil stack. Int J Mass Spectrom 444:116175

24. Merchel S, Bremser W (2004) First international ${ }^{26} \mathrm{Al}$ interlaboratory comparison-Part I. Nucl Instr Meth B 223:393-400

25. Rugel G, Pavetich S, Akhmadaliev S, Enamorado Baez SM, Scharf A, Ziegenrücker R, Merchel S (2016) The first four years of the AMS-facility DREAMS: Status and developments for more accurate radionuclide data. Nucl Instr Meth B 370:94-100

26. Lachner J, Martschini M, Kalb A, Kern M, Marchhart O, Plasser F, Priller A, Steier P, Wieser A, Golser R (2021) Highly sensitive ${ }^{26} \mathrm{Al}$ measurements by Ion-Laser-InterAction Mass Spectrometry. Int J of Mass Spectrom 465:116576

27. Breiter K, Ackerman L, Durisova J, Svojtaka M (2014) Trace element composition of quartz from different types of pegmatites: a case study from the Moldanubian Zone of the Bohemian Massif (Czech Republic). Mineral Mag 78(3):703-722

Publisher's Note Springer Nature remains neutral with regard to jurisdictional claims in published maps and institutional affiliations. 